\title{
BARLEY CHLOROPLASTS CONTAIN TWO ACYL CARRIER PROTEINS CODED FOR BY DIFFERENT GENES
}

\author{
by \\ PETER BORDIER HØJ' ${ }^{1.2)}$ and IB SVENDSEN ${ }^{3 \prime}$ \\ " Department of Physiology, Carlsberg Laboratory, \\ Gamle Carlsberg Vej 10, DK-2500 Copenhagen Valby \\ 2) Institute of Genetics, University of Copenhagen \\ Øster Farimagsgade 2A, DK-1353 Copenhagen K \\ "Department of Chemistry, Carlsberg Laboratory, \\ Gamle Carlsberg Vej 10, DK-2500 Copenhagen Valby
}

Keywords: Fatty acid synthetase, sequence homology, protein purification.

\begin{abstract}
A second chloroplast acyl carrier protein (denoted ACP II) has been purified to homogeneity from greening barley seedlings. Both the previously characterized ACP I and ACP II are active in fatty acid synthesis but differ significantly in their amino acid composition. Comparison of the amino-terminal sequences of the two proteins reveals striking differences as indicated by the underlines. ACP II: $\mathrm{NH}_{2}$-AKKETVEKV?DIVKSQLALSDDDE-, ACP I: $\mathrm{NH}_{2}$-AAMGEAQAKKETVDKV(C?)MIVKKQLAVPDGTP-. We thus deduce that the two ACPs are coded for by different genes. Both ACPs are present in dark and light grown seedlings although in sligthly different proportions. The possible functional significance of two or more ACPs within the chloroplast is discussed in relation to plant fatty acid and glycerolipid biosynthesis.
\end{abstract}

\section{INTRODUCTION}

Acyl carrier protein (ACP) which functions as a coenzyme in the synthesis and subsequent metabolism of fatty acids in plants and bacteria $(5,19,26)$ has been isolated from a variety of sources $(1,4,10,16,21,25,29)$. An ACP purified from barley and E. coli ACP show extensive sequence homology (10). Despite the absence of nine $\mathrm{N}$-terminal amino acids in the $\mathrm{E}$. coli protein $(10)$ it functions effectively with plant fatty acid synthetases $(10,25)$. Such recombination experiments are possible because both plant and $\mathrm{E}$. coli fatty acid synthe- tases (FASes) consist of discrete enzymes plus $\operatorname{ACP}(3,9,23,24)$. Already 12 years ago the first evidence was obtained suggesting that two FAS systems are involved in the conversion of acetate to stearic acid $\left(\mathrm{C}_{18}\right)$ in plants $(8,9,11)$. Recently the molecular basis for this was revealed by SHIMAKATA and STUMPF who demonstrated the existence of two different $\beta$-ketoacyl ACP synthetases in spinach: One was involved in joining the first eight $C_{2}$ units together to give palmitic acid $\left(\mathrm{C}_{16}\right)$ while a second was responsible for elongating $\mathrm{C}_{16}$ to $\mathrm{C}_{18}$ (22). In E. coli at least two functional FAS systems exist which give rise

Abbreviations: $\mathrm{ACP}=$ acyl carrier protein; $\mathrm{CoA}=$ coenzyme $\mathrm{A} ; \mathrm{DTT}=1,4$-dithiotreitol; $\mathrm{FAS}=$ fatty acid synthetase; HEPES $=\mathrm{N}$-2-hydroxyethylpiperazine-N'-2-ethane sulfonic acid; MOPS $=3$-(N-Morpholino)-propane sulfonic acid; $\mathrm{MW}=$ molecular weight; SDS-PAGE = sodium dodecyl sulfate polyacrylamide gel electrophoresis; TRICINE $=\mathrm{N}$-(tris(hydroxymethyl)methyl)-glycine 
to different products. Not only are two $\beta$-ketoacyl ACP synthetases known (determined by the genes fab $B$ and fab F) (6) but also two $\beta$-hydroxydecanoyl ACP thioester dehydrases (2) and two enoyl ACP reductases (30). On the basis of the just summarized observations it was deemed worthwhile to explore the question as to whether more than one ACP protein exists in barley chloroplasts especially as the literature suggests this possibility not only for barley $(9,10)$ but also for spinach (15). This paper describes the purification to homogeneity of a second barley ACP and provides conclusive evidence that the two ACPs are coded for by different genes.

\section{MATERIALS AND METHODS}

\subsection{Biological material}

Seeds of wild type barley (Hordeum vulgare cv. Svalöfs Bonus) were germinated and grown for six days on moist vermiculite in a dark room maintained at $23{ }^{\circ} \mathrm{C}$ and 70 to $80 \%$ relative humidity. Seedlings were harvested after six hours exposure to continuous white light $(1,700$ lux) with other conditions being unchanged. $E$. coli B was a kind gift from Dr. J. PRICE, University of California, Davis.

\subsection{Analytical material}

Bovine serum albumin was purchased from Merck. N-2-hydroxyethylpiperazine-N'-2-ethanesulfonic acid (HEPES), N-(Tris(hydroxymethyl)methyl)glycine (TRICINE), morpholinopropanesulfonic acid (MOPS), coenzyme A $(\mathrm{CoA})$ and polyvinyl pyrrolidine (insoluble) came from Sigma. DEAE-Sepharose CL 6B, Octyl-Sepharose CL 4B, Polybuffer exchanger 94, Polybuffer 74, Sephacryl S-300 plus Sephadex G75 SF were products of Pharmacia, Sweden. $\left(2-{ }^{14} \mathrm{C}\right)$-malonyl-CoA $\left(6.4 \mathrm{mCi} \times \mathrm{mmol}^{-1}\right)$ (9), $\left(1-{ }^{14} \mathrm{C}\right)$-acetyl-CoA $\left(5.3 \mathrm{mCi} \mathrm{mmol}^{-1}\right)(9)$ and pure E. coli ACP (14) were prepared. Unless otherwise specified all other chemicals were of analytical grade and used without further purification.

\subsection{Preparation of plant extracts}

A total of ca. $3 \mathrm{~kg}$ leaves was harvested and homogenised $2 \times 1 \mathrm{~min}$ at topspeed in a blender with replaceable razor blades (12). Per $300 \mathrm{~g}$ of leaves $500 \mathrm{ml}$ of pH 9.0 medium $(0.6 \mathrm{M}$-glycerol, $0.1 \mathrm{M}$-TRICINE- $\mathrm{NaOH}$ at $\mathrm{pH}$ 9.0, $2 \mathrm{~mm}$-DTT) or pH 7.0 medium (20 mM-MOPS- $\mathrm{NaOH}$ at $\mathrm{pH}$ 7.0,2 mM-DTT, $1 \%(\mathrm{w} / \mathrm{v})$ polyvinyl pyrrolidine, $500 \mathrm{mM}-\mathrm{NaCl}$ ) were used. The homogenate was squeezed through a single layer of $31 \mu \mathrm{m}$ mesh nylon gauze and then filtered through another identical gauze layer. The filtrate so obtained was used as homogenization media for the next $300 \mathrm{~g}$ lot of seedlings which were homogenized in the same manner. The final homogenate (approx. $4 \mathrm{l}$ ) was centrifuged at $5,000 \times \mathrm{g}$ for 45 min and the resulting supernatant subjected to $\left(\mathrm{NH}_{4}\right)_{2} \mathrm{SO}_{4}$ fractionation. $\left(\mathrm{NH}_{4}\right)_{2} \mathrm{SO}_{4}$ was added gradually with stirring to $70 \%$ saturation and then left stirring for an additional $30 \mathrm{~min}$ before centrifugation at $5,000 \times \mathrm{g}$ for $45 \mathrm{~min}$. ACP was recovered from the supernatant by adding 0.2 $\mathrm{mg} \times \mathrm{ml}^{-1}$ bovine serum albumin, adjusting the $\mathrm{pH}$ to 1.0 with conc. $\mathrm{HCl}$ and adding solid $\left(\mathrm{NH}_{4}\right)_{2} \mathrm{SO}_{4}$ to $100 \%$ saturation. The solution was left stirring overnight whereupon precipitable proteins were collected by centrifugation at $5,000 \times \mathrm{g}$ for 1 hour. Pelleted protein was suspended in $1 \mathrm{M}$-HEPES (pH 7.5) and the $\mathrm{pH}$ adjusted to 7.0 by addition of $1 \mathrm{M}-\mathrm{NaOH}$. After dialysis overnight towards 50 vols of $20 \mathrm{~mm}$ MOPS- $\mathrm{NaOH}$ at $\mathrm{pH} 7.0$ fortified with $1 \mathrm{~mm}$ DTT (Buffer A), the solution was either used immediately or stored at $-20^{\circ} \mathrm{C}$ before further purification. The protein extraction and all other subsequent procedures were carried out at 4-6 ${ }^{\circ} \mathrm{C}$ unless otherwise stated.

\subsection{Purification of ACPs from $\left(\mathrm{NH}_{4}\right)_{2} \mathrm{SO}_{4}-$ fractionated leaf extracts}

As summarized in the flow chart of Figure 1, dialysed material from $15 \mathrm{~kg}$ of seedlings was applied to a DEAE-Sepharose CL 6B column $(5 \times 41 \mathrm{~cm})$ previously equilibrated in buffer $A$, and the column was washed with 11 of the same buffer to remove non-adsorbed material. Adsorbed proteins were eluted using $5 \mathrm{l}$ of $\mathrm{NaCl}$ in buffer $\mathrm{A}$ in a linear gradient $(0.12 \mathrm{M}-0.4$ M) $-\mathrm{NaCl}$. Analyses of the column fractions for ACP activity gave the results illustrated in Figure 2. Fractions 171 - 215 (Figure 2) were pooled and dialysed against $10 \mathrm{vol}$ of buffer $\mathrm{A}$ and 

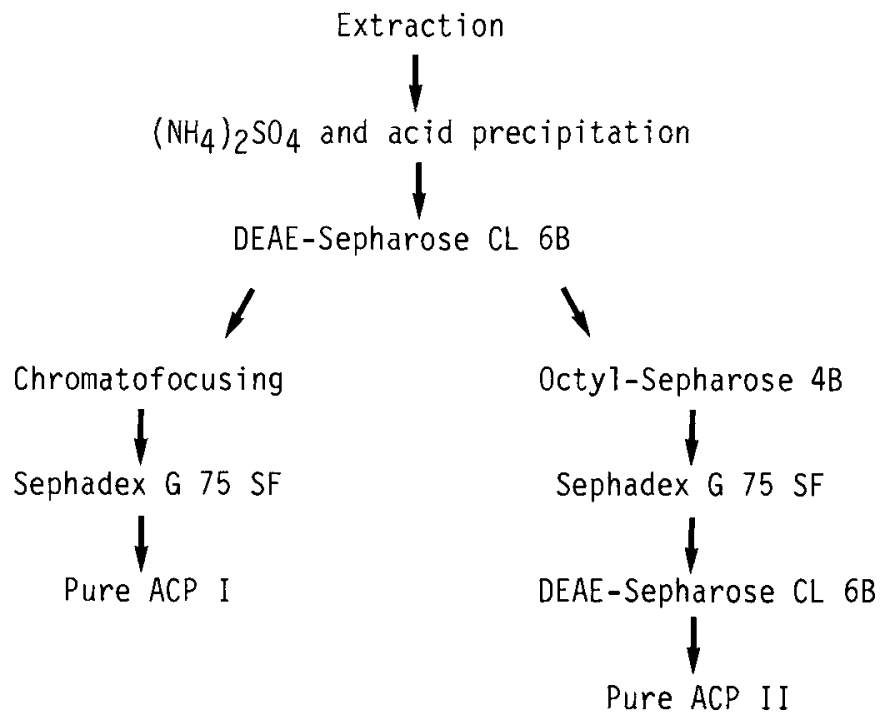

Figure 1. Flow scheme for isolation and purification of barley ACPs I and II.

subsequently against $5 \mathrm{vol}$ of $25 \mathrm{mM}$-histidine$\mathrm{HCl}$ at $\mathrm{pH} 5.9$ containing $2 \mathrm{~mm}$-DTT to give a final conductivity of $4.3 \mathrm{mS}$. The material after dialysis was applied to a column $(1.6 \times 30 \mathrm{~cm})$ of Polybuffer exchanger 94 equilibrated in the histidine buffer. Elution of bound material was done by using nine-fold diluted Polybuffer 74 at pH 3.6 fortified with $2 \mathrm{~mm}$-DTT. Fractions rich in $A C P$ were pooled and concentrated on a $2 \mathrm{ml}$ DEAE-Sepharose CL 6B column to a volume of $5 \mathrm{ml}$. Using a flowrate of $7 \mathrm{ml} \times \mathrm{hr}^{-1}$ and fraction sizes of $2.3 \mathrm{ml}$ the concentrated solution was fractionated further on a column $(1.6 \times 88 \mathrm{~cm})$ of Sephadex G75 SF equilibrated in Buffer $A$ and $150 \mathrm{~mm}-\mathrm{NaCl}$. Active fractions were pooled and sodium dodecylsulphate polyacrylamide gel electrophoresis (SDS-PAGE) (13) plus amino acid analysis revealed that this preparation designated ACP I was identical to the ACP of barley seedlings previously studied (10).

The material in fractions $242-275$ (Figure 2) was applied directly to a column $(2.5 \times 9.0 \mathrm{~cm})$ of Octyl-Sepharose CL 4B equilibrated in buffer $A$. Bound material was eluted using a $200 \mathrm{ml} 0-60 \%$ $(\mathrm{v} / \mathrm{v})$ linear gradient of ethylene glycol in buffer A. Fractions with ACP activity were analysed by SDS-PAGE. Those with the highest activity and simplest polypeptide pattern were pooled, concentrated by ion exchange as above and further fractionated on the Sephadex G-75 SF column.

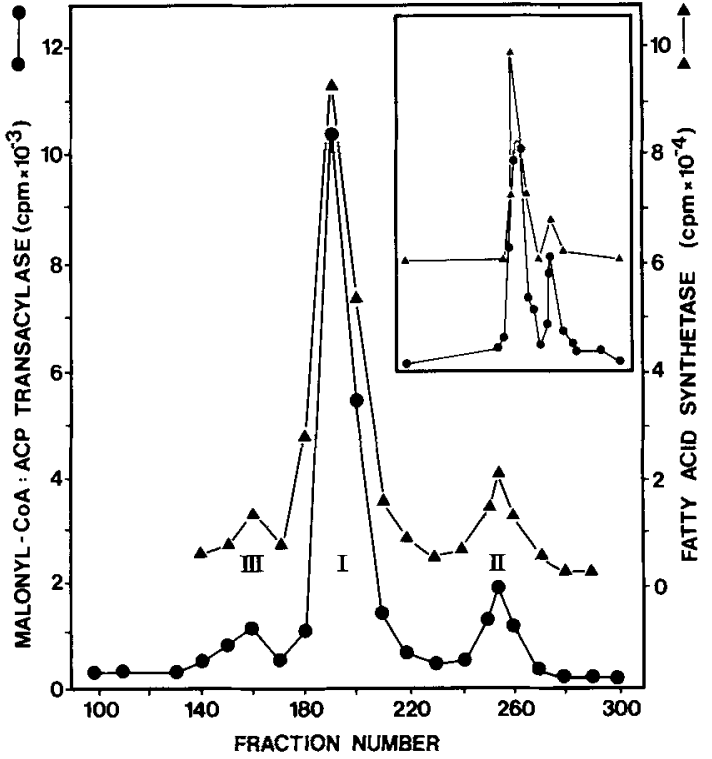

Figure 2. Separation of barley leaf ACPs by ion exchange on a column $(5 \times 4 \mathrm{~cm})$ of DEAE-Sepharose $\mathrm{CL}$ 6B (2.4). $15 \mathrm{~kg}$ leaves were homogenized in the $\mathrm{pH} 9.0$ medium and handled as in 2.4. From each $18 \mathrm{ml}$ fraction $150 \mu \mathrm{l}$ and $600 \mu \mathrm{l}$ were used for assaying with malonyl-CoA:ACP transacylase and FAS, respectively. I, II and III are the designations given to the three peaks corresponding to their relative activities. The insert shows a two headed curve of ACP activity obtained when subjecting extracts from isolated chloroplasts to chromatography on DEAE-Sepharose CL 6B (9). 
Again the ACP containing fractions were analysed by SDS-PAGE. If not homogenous the preparation was loaded onto a column $(0.9 \times 10$ $\mathrm{cm}$ ) of DEAE-Sepharose CL $6 \mathrm{~B}$ previously equilibrated in $20 \mathrm{mM}$-HEPES at $\mathrm{pH} 7.0$ containing $1 \mathrm{mM}$-DTT. Elution was performed using a linear $\mathrm{NaCl}$ gradient $(0.175-0.45 \mathrm{M})$ in $240 \mathrm{ml}$ buffer A. Flowrate and fraction size were 20 $\mathrm{ml} \times \mathrm{hr}^{-1}$ and $2.2 \mathrm{ml}$, respectively. Fractions with ACP activity showing a single band on SDSPAGE were pooled, dialysed against $\mathrm{H}_{2} \mathrm{O}$ containing $0.5 \mathrm{~g} \mathrm{NaCl} / 1,2 \mathrm{mM}$-DTT and lyophilized before composition and sequence analysis (section 2.6). Fractions 141-166 (Figure 2) were pooled and concentrated by pressure dialysis in an Amicon cell fitted with a PM 10 Diaflo-Ultrafiltration membrane to a volume of $30 \mathrm{ml}$. Fractionation according to size was achieved by layering the concentrated solution on top of a $5 \times 91 \mathrm{~cm}$ Sephacryl S-300 column previously equilibrated with $100 \mathrm{mM}-\mathrm{TRICINE} / \mathrm{NaOH}$ at $\mathrm{pH} 9.0,2 \mathrm{~mm}$-in DTT and $0.3 \mathrm{M}$ in glycerol. Calibration of the column was as described (9). The column was eluted at $76 \mathrm{ml} \mathrm{hr}^{-1}$ and the eluate collected in $9.5 \mathrm{ml}$ fractions.

\subsection{Enzyme assays}

Barley ACP was determined as detailed (10). The activity of barley ACP preparations in fatty acid synthesis was assayed by the addition of the specified amounts to $650 \mu$ l of a mixture containing 19.4 nmoles of $\left(2-{ }^{14} \mathrm{C}\right)$-malonyl-CoA, 5.6 nmoles of $\left(1{ }^{14} \mathrm{C}\right)$-acetyl-CoA, $1.2 \mu$ moles of ATP, $1.2 \mu$ moles of NADPH, $0.65 \mu$ moles of $\mathrm{NADH}$ and $8 \mathrm{mg}$ of barley chloroplast FAS partially purified by $\left(\mathrm{NH}_{4}\right)_{2} \mathrm{SO}_{4}$ fractionation as in (9). The products of fatty acid synthesis were analysed as described previously (9).

\subsection{Amino acid composition and sequence determination}

For amino acid analysis samples were hydrolyzed in nitrogen flushed evacuated ampoules with $5.7 \mathrm{~N} \mathrm{HCl}$ for 24 hours at $110^{\circ} \mathrm{C}$, dried and analyzed on a Durrum D 500 analyzer. Amino acid sequences were determined using an automatic liquid phase sequencer Beckmann model $890 \mathrm{C}$, and phenylthiohydantoin amino acids were identified by high pressure liquid chromatography (27).

\section{RESULTS}

\subsection{Purification of barley ACPs}

Barley seedlings greened for 6 hours were homogenized in the $\mathrm{pH} 7.0$ medium or alternatively in the $\mathrm{pH} 9.0$ medium and the resulting extracts subjected to the purification scheme outlined in Figure 1. Upon the initial ion exchange fractionation (Figure 2) a three headed curve of ACP activity was obtained when assayed for with malonyl-CoA ACP transacylase. An identical profile was obtained when the effluent was assayed for its ability to stimulate fatty acid synthesis catalyzed by $40-70 \%$ $\left(\mathrm{NH}_{4}\right)_{2} \mathrm{SO}_{4}$ precipitated barley chloroplast FAS. The relative sizes of the three peaks did not depend on the extraction buffer used. These results suggest that three putatively different

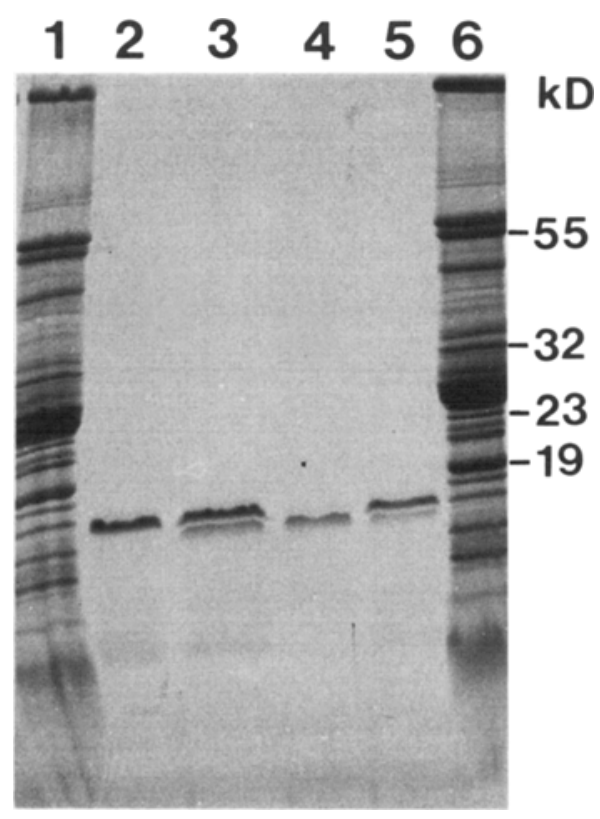

Figure 3. SDS-PAGE of ACP I and II purified from whole leaf extracts. The separation was carried out in a system II $11-15 \%$ linear gradient gel at $10{ }^{\circ} \mathrm{C}$ (13). ACP I was applied in lanes 2, 3, 5, ACP II in lanes $3,4,5$ and barley wild type thylakoid proteins (13) in lanes 1,6. Proteins were visualized with Coomassie Brilliant Blue. 
Table I.

Amino acid compositions of barley ACP I and II

\begin{tabular}{|c|c|c|c|c|c|c|c|c|c|}
\hline \multirow{3}{*}{ amino acid } & \multicolumn{3}{|c|}{ ACP I" } & \multicolumn{3}{|c|}{ ACP I } & \multicolumn{3}{|c|}{ ACP II } \\
\hline & \multirow[b]{2}{*}{ mole $\%{ }^{2 y}$} & \multicolumn{2}{|c|}{ moles $^{3}$} & \multirow[b]{2}{*}{ mole $\%^{2)}$} & \multicolumn{2}{|c|}{ moles $^{31}$} & \multirow[b]{2}{*}{ mole\%" } & \multicolumn{2}{|c|}{ moles $^{41}$} \\
\hline & & mole & $\mathrm{ACP} 1$ & & mole & ACP I & & mole & ACP II \\
\hline Asp & 10.1 & 9 & $(8.5)$ & 10.4 & 9 & $(9.1)$ & 11.8 & 9 & (8.9) \\
\hline Thr & 9.0 & 8 & $(7.6)$ & 8.9 & 8 & $(7.7)$ & 7.1 & 5 & (5.3) \\
\hline Ser & 4.6 & 4 & $(3.9)$ & 4.9 & 4 & (4.3) & 10.6 & 8 & $(8.0)$ \\
\hline Glu & 17.4 & 15 & $(14.6)$ & 17.2 & 15 & $(15.0)$ & 15.3 & 12 & (11.5) \\
\hline Pro & 3.1 & 3 & $(2.6)$ & 3.4 & 3 & $(3.0)$ & 1.6 & 1 & $(1.2)$ \\
\hline Gly & 4.8 & 4 & $(4.0)$ & 6.6 & 6 & $(5.8)$ & 7.1 & 5 & (5.3) \\
\hline Ala & 13.0 & 11 & $(10.9)$ & 13.1 & 11 & (11.4) & 10.6 & 8 & (8.0) \\
\hline Val & 10.2 & 9 & $(8.6)$ & 9.2 & 8 & $(8.0)$ & 10.4 & 8 & $(7.8)$ \\
\hline Met & 3.1 & 3 & $(2.6)$ & 2.9 & 3 & (2.5) & 1.2 & 1 & $(0.9)$ \\
\hline Ile & 4.4 & 4 & (3.7) & 4.3 & 4 & (3.7) & 5.5 & 4 & (4.1) \\
\hline Leu & 7.1 & 6 & $(6.0)$ & 6.9 & 6 & $(6.0)$ & 9.3 & 7 & $(7.0)$ \\
\hline Tyr & 0.2 & 0 & $(0.2)$ & 0.3 & 0 & $(0.3)$ & 0.7 & $0^{51}$ & $(0.5)$ \\
\hline Phe & 2.0 & 2 & $(1.7)$ & 2.3 & 2 & $(2.0)$ & 2.3 & 2 & $(1.7)$ \\
\hline His & 0.4 & 0 & $(0.3)$ & 0.3 & 0 & $(0.3)$ & 0.3 & 0 & $(0.2)$ \\
\hline Lys & 9.0 & 8 & (7.6) & 8.4 & 7 & $(7.3)$ & 6.3 & 5 & $(4.7)$ \\
\hline Arg & 0.0 & 0 & $(0.0)$ & 0.7 & 1 & $(0.6)$ & 0.0 & 0 & $(0.0)$ \\
\hline Trp & 0.0 & 0 & $(0.0)$ & n.d. & n.d. & & n.d. & n.d. & \\
\hline Cys & 1.5 & 1 & (1.3) & n.d. & n.d. & & n.d. & n.d. & \\
\hline B-Ala & - & 1 & $(0.9)$ & - & 1 & $(1.2)$ & - & 1 & $(1.0)$ \\
\hline $\begin{array}{l}\text { Total } \\
\text { exclusive } \\
\beta \text {-Ala }\end{array}$ & & & 87 & & & 87 & & & 75 \\
\hline \multicolumn{10}{|c|}{$\begin{array}{l}\text { 2) } 24 \text { hours hydrolysis. Uncorrected for loss of threonin } \\
\text { (3) Calculated on the basis of six leucine residues per m } \\
\text { 4) Calculated on the basis of eight alanine residues per } \\
\text { 5) Supported by spectroscopic data (not shown). } \\
\text { (6) n.d. = not determined }\end{array}$} \\
\hline
\end{tabular}

ACPs exist in our initial extract. They have been designated ACP I, ACP II and ACP III in order of descending peak size (Figure 2).

ACP I and ACP II were purified as detailed in section 2.4 from fractions $171-215$ and $242-275$, respectively (Figure 2). SDS-PAGE analysis of the final protein preparations from $\mathrm{pH} 7.0$ extracts is shown in Figure 3. Since both ACPs appear as single bands they are considered to be purified to homogeneity with ACP II having a higher electrophoretic mobility than ACP I. Using barley wild type thylakoid proteins as molecular weight (MW) markers (13), we es- timate apparent MWs of 17.0 and $15.5 \mathrm{kD}$ for ACP I and ACP II, respectively (Figure 3). Using another set of reference proteins but the same gel system we reported the apparent $M W$ of an $A C P$ to be $22 \mathrm{kD}(10)$, however, the true MW of these proteins is ca. $9-10 \mathrm{kD}$, a discrepancy probably due to the acidic nature of the protein (10). The yield of pure ACP II and ACP I when using the $\mathrm{pH} 7.0$ extraction medium was 70 and 230 nmoles per $15 \mathrm{~kg}$ seedlings, giving a purification of greater than 10,000 fold for both ACPs (10). Fractions 141-166 containing the reputed ACP III was fractionated by gel filtration on Sephacryl 


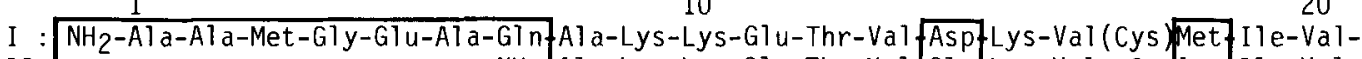
II: $\mathrm{NH}_{2} \mathrm{Al}_{1}$ a-Lys-Lys-GTu-Thr-Val GlufLys-Val- ? Asp Il le-Val-

30

I : Lys Lys Gin-Leu-Al a Val-ProfAsp Gly-Thr-Pro

II : Lys SerfGIn-Leu-Ala LLeu-Ser-AsptAsp-Asp-Gluf

Figure 4. Comparison of the amino terminal sequences of barley leaf ACP I and II. Numbers of the amino acid positions are given above or below the individual ACPs. Residues which differ in the two molecules are enclosed in boxes. Brackets indicate uncertainty (see text).

S 300. The ACP activity eluted from the calibrated column with an apparent MW of $21 \mathrm{kD}$. When aliquots from the eluted fractions were subjected to SDS-PAGE analysis it was noted that the peak fractions were specifically enriched in one major component (out of five) having a mobility similar to that of ACP I and II. Due to the small amounts of ACP III further attempts to purify it failed. As reported earlier (9) we repeatedly obtain only two headed curves for ACP activity when using the chloroplasts isolated from greening barley leaves as starting material. We assume that the missing peak is that attributable to ACP III. The reason why we do not see an ACP III component is not clear but it could be due either to its absence from the chloroplasts or simply because our assays are not sensitive enough.

\subsection{Amino acid composition of barley ACPs I and II}

Amino acid composition analyses showed distinct differences between ACP I and ACP II (Table I) and further confirmed that ACP I is identical to the major ACP of greening barley seedlings (10). Significant differences are observed for a number of the amino acids. Finding that the number of amino acids per $\beta$-alanine residue is 76 accords with the conclusion drawn above that the ACP II preparation is not contaminated significantly by other proteins and reveals that the amount of apo-ACP II molecules is negligible. The estimated number of amino acids given here for ACP I and II (Table I) corroborates the apparent MW differences of the two ACPs as estimated by SDS-PAGE (Figure 3).

\subsection{Amino terminal sequence of ACP II}

Automated sequence analysis was performed in duplicate with 15 nmoles of ACP II isolated from $\mathrm{pH} 7.0$ extracts and in duplicate with 50 nmoles isolated from $\mathrm{pH} 9.0$ extracts. This allowed the determination of the first 24 residues except for cycle 10 where no PTH derivative was detectable probably due to the presence of a cysteine residue (10). The amino-terminal sequence so obtained for ACP II is shown in Figure 4 where it is compared to that of ACP I (10). The sequence analysis confirmed that ACP II was completely free of ACP I. Finding 8 substitutions per 24 residues plus an amino-terminal extension of ACP I by seven residues relative to ACP II was initially surprising. A comparison of Table I and Figure 4, however, shows that the differences in amino acid composition of ACP I and II correlate well with the determined amino acid sequences. For instance, it is predicted on the basis of the compositional analysis that $\mathrm{ACP}$ II contains three Ala, two Pro and two Met residues less than ACP I. From the sequences determined it is seen that three Ala, two Pro and two Met residues present in ACP I have been deleted from or substituted for by other residues in ACP II. The high frequency of substitution observed in the $\mathrm{NH}_{2}$-terminal part of the molecule is unlikely to extend throughout the molecule since the unsequenced segment contains the prosthetic group attachment site which has been found to be highly conserved amongst several species $(10,17,18)$. We thus predict that the single Met residue of ACP II, for example, is located at an analogous position to that of the third Met in ACP I and the single Met in E. coli $\operatorname{ACP}(10,29)$. 


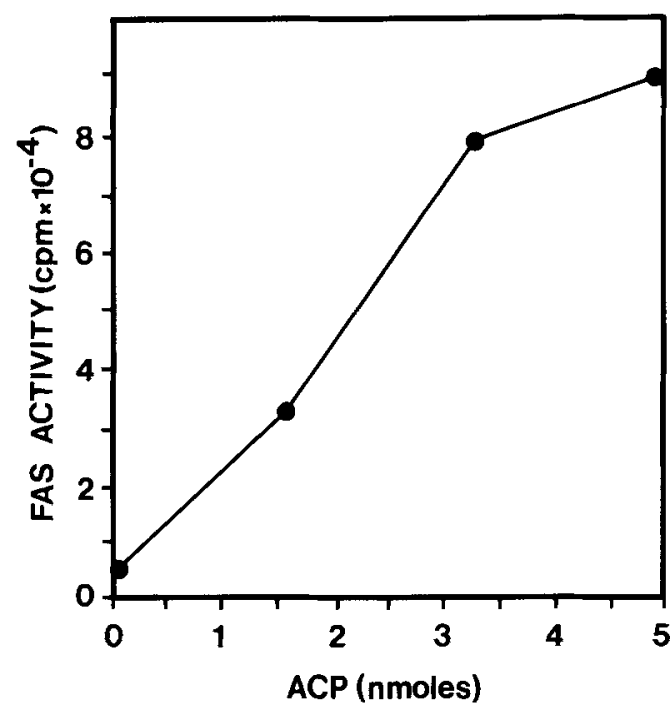

Figure 5. The effect of ACP II on fatty acid synthesis. The assay using barley chloroplast FAS partially purified by $\left(\mathrm{NH}_{4}\right)_{2} \mathrm{SO}_{4}$ precipitation was done as described in section 2.5 with the indicated amounts of ACP II in a final volume of $1.55 \mathrm{ml}$. ACP IJ was quantitated by amino acid analysis.

\subsection{Occurrence of ACPs in light and dark grown seedlings}

Two kg of barley seedlings grown either continuously in the light for six days or continuously in the dark for six days were extracted with the pH 9.0 medium. $\left(\mathrm{NH}_{4}\right)_{2} \mathrm{SO}_{4}$ precipitation, acid precipitation and dialysis were carrried out as detailed in section 2.3. The preparations from light and dark grown plants were fractionated separately on a column $(2.5 \times 25 \mathrm{~cm})$ of DEAESepharose CL 6B equilibrated in Buffer A. Bound material was eluted by applying a linear $\mathrm{NaCl}$ gradient $(0.12-0.45 \mathrm{M}, 1,200 \mathrm{ml}$ total $)$ in buffer A. ACP activity was located using malonyl-CoA:ACP transacylase and the appropriate fractions pooled. Both ACP I and ACP II were present in the light as well as dark grown material although there was a tendency for ACP I to increase relative to ACP II upon light exposure. Thus, in this experiment, we found the ratios of ACP II to ACP I to be $0.18,0.25$ and 0.32 for seedlings grown in continuous dark, continuous dark but greened for six hours (from experiments in Figure 2) and continuous light, respectively.

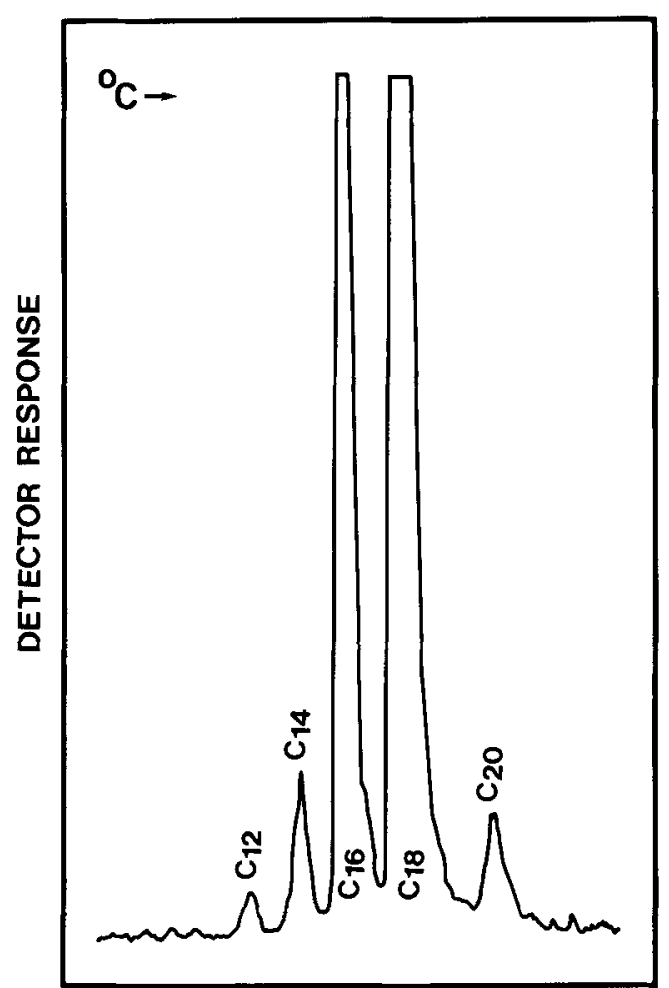

Figure 6. Radio-gas chromatograpic analysis of products synthesized by barley chloroplast FAS (see 2.5) with 3.3 nmoles of ACP II in a final volume of 1.55 $\mathrm{ml}$. The ${ }^{34} \mathrm{C}$-trace shown was obtained after reaction of free fatty acids with diazomethane and subsequent separation on a Silar 10 C column, operated essentially as detailed previously (9).

\subsection{Barley ACP II in fatty acid synthesis}

Figure 5 illustrates that increasing amounts of ACP II up to 5 nmoles markedly increased total fatty acid synthesis without reaching a saturation level. That barley ACP II gave identical products to those obtained with E. coli ACP and barley ACP I, predominantly palmitic and stearic acids plus small amounts of lauric, myristic and eicosanoic acids is shown in Figure 6.

\section{DISCUSSION}

The results presented in this paper show that greening barley seedlings contain at least two, possibly three, different ACPs. Two of these (ACP I and II) have been purified to homogeneity and partially sequenced. In view of the striking differences in amino acid composition 
and amino-terminal sequence we conclude that the two purified ACPs are determined by different genes. We find it unlikely that the proteins originate from different alleles at a single locus since barley is predominantly self-fertilizing and the used cultivar essentially homozygous. To the best of our knowledge only ferredoxin has previously been shown to exist as isozymes in plant chloroplasts (28). A major and a minor ferredoxin component have been isolated from spinach. Comparison of the 34 amino-terminal residues showed $11(32 \%)$ substitutions, and it was concluded that the two spinach ferredoxins were coded for by two independent genes derived by gene duplication a long time ago on the evolutionary scale. The ratio of the two ferredoxins varied under different physiological conditions, that is the "second" ferredoxin accounted for only $20 \%$ of the total ferredoxin in leaves grown to maturity but $55 \%$ in darkgrown leaves (28). These figures can be compared to the $8(33 \%)$ substitutions found in the 24 sequenced positions of the two barley ACPs and the noted potential difference in the relative amounts of the latter under different light conditions.

The functional significance of the presence of two ACPs in vivo is not yet known. The ability of both of them to sustain fatty acid synthesis in vitro does not necessarily mean that they carry out identical functions in vivo. E. coli ACP for example functions in vitro in plant fatty acid and glycerolipid biosynthesis and even acyl-CoA derivatives are active in glycerolipid biosynthesis although they most probably do not act as the physiological acyl-donors (5). The noted differences in primary structure of the aminoterminal end of barley ACP I and II suggests a potential to interact differently with different ACP dependent enzymes and it is conceivable therefore that they carry out distinct functions in vivo. One ACP might participate in de novo fatty acid synthesis while the other participates in glycerolipid biosynthesis. By means of an acyltransferase, acyl-groups could be transferred to "free" ACP (e.g. II) from acyl-ACP I organized in an active FAS complex. The generated acylACP II could then act as acyl donor in glycerolipid biosynthesis.

It is generally accepted that fatty acid synthesis in plant leaf mesophyll cells is completely dependent upon $\mathrm{ACP}$ and that $\mathrm{ACP}$ is exclusively located in the plastids (20). The latter conclusion was reached by OHLROGGE et al. after using protoplasts and rabbit anti spinach ACP IgG in a radio-immunoassay. Although not shown conclusively the literature suggests that spinach contains two acyl carrier proteins (15) as does E. coli (7). During recent years it has been assumed, however, that plants have only one ACP. In order for the conclusions of OHLROGGE et al. (20) to hold it is of crucial importance that the antibodies used in that study were raised against a mixture of ACPs or alternatively that the antibodies are crossreactive. Despite the striking differences in the amino-terminal segment of the two isolated barley ACPs, a great deal of homology is expected between the other two thirds of the two proteins (see 3.3). Thus we expect that among the antibodies raised against either enzyme will be crossreactive ones as has been observed for two $\beta$-glucanases isolated from germinating barley $(31,32)$. Polyclonal antibodies against ACP I have been obtained. In a preliminary experiment by one of us (PBH) a rabbit reticulocyte lysate was used to translate the mRNA isolated from greening barley leaves and purified by adsorption to poly-U Sepharose. Crude rabbit anti barley ACP I serum, but not preimmune serum, precipitated two polypeptides which by SDS-PAGE showed an approximate apparent MW of 18-19 kD and MW difference of $1 \mathrm{kD}$. This observation lends strong support to the contention that plant ACP $I$ and II are immunologically cross reactive and further corroborates the finding that two separate $\mathrm{ACP}$ genes are expressed in barley.

The presence of more than one ACP in barley leaves renders it uncertain whether rigoristic conclusions can be drawn about specificity, kinetic parameters etc. when E. coli ACP is used as a substitute for plant $\mathrm{ACP}$ in a plant lipid synthesizing system. We found for instance that the chain length distribution of fatty acids synthesized by barley chloroplast FAS did not respond significantly to varying concentrations of E. coli ACP but markedly to varying concentrations of barley ACP I (10). Because plant ACPs are present at very low levels $(<0.1 \%$ of the soluble protein), it is at present hardly feasible 
to explore specificities of the two isozymes from plants. In order to surmount this problem, cloning of a plant $\mathrm{ACP}$ gene into an expression vector yielding reasonable amounts of the gene product is necessary.

\section{ACKNOWLEDGEMENTS}

PENNY VON WETTSTEIN-KNOWLES and J.D MIKKELSEN are thanked for encouragement and practical advice throughout this work. Thanks are also due to R.v.HEEswiJCK. C.G. Kannangara and B.L. Møller for helpful discussions. We thank Merete Petersen. BODIl CORNELIUSSEN and LONE SØrensen for excellent technical assistance. NINA RASMUSSEN is thanked for drawing the figures.

\section{REFERENCES}

1. Ailmaud, G.P., P.R. Vagelos \& H. Goldfine: Involvement of acyl carrier protein in acylation of glycerol 3-phosphate in Clostridium butyricum. J. Biol. Chem. 242, 4459-4465 (1967)

2. BLOCK, K.: The $\beta$-hydroxydecanoyl thioester dehydrase. Enzymes 3rd Ed. 5, $441-464$ (1971)

3. CaugheY, I. \& R.G.O. KeCKWICK: The characteristics of some components of the fatty acid synthetase system in the plastids from the mesocarp of avocado(Persea americana) fruit. Eur. J. Biochem. 123, 553-561 (1982)

4. Dinello, R.K. \& M.L. ERnSt-Fonberg: Purification and partial characterization of an acyl carrier protein from Euglena gracilis. J. Biol. Chem. 248, 1707-1711 (1973)

5. Frentzen. M., E. Heinz, T.A. MCKeon \& P.K STUMPF: Specificities and selectivities of glycerol3-phosphate acyltransferase and monoacylglycerol-3-phosphate acyltransferase from pea and spinach chloroplasts. Eur. J. Biochem. 129, 629636 (1983)

6. Garwin, J.L., A. Klages \& J.E. Cronan: Structural, enzymatic and genetic studies of $\beta$-ketoacylacyl carrier protein synthetases I and II of Escherichia coli. J. Biol. Chem. 255, $11949-11956$ (1980)

7. Goldman. P.A., A.W. Alberts \& P.R. Vagelos: The condensation reaction of fatty acid synthesis. J. Biol. Chem. 238, 3579-3583 (1983)

8. Harwood, J.L \& P.K. STumpF: Fat metabolism in higher plants. Palmitic and stearic acid synthesis by an avocado supernatant system. Arch. Bioch. Biophys. 148, 282-290 (1972)
9. HøJ, P.B. \& J.D. MikKelSEN: Partial separation of individual enzyme activities of an ACP-dependent fatty acid synthetase from barley chloroplasts. Carlsberg Res. Commun. 47, 119-141 (1982)

10. Høנ. P.B. \& I. SVENDSEN: Barley acyl carrier protein: Its amino acid sequence and assay using purified malonyl-CoA:ACP transacylase. Carlsberg Res. Commun. 48, 285-305 (1983)

11. JAWORSKI, J.G., E.E. GOLDSCHMIDT \& P.K STUMPF: Fat metabolism in higher plants. Properties of the palmityl acyl carrier protein: stearyl acyl carrier protein elongation system in maturing safflower seed extracts. Arch. Biochem. Biophys. 163, 769-776 (1974)

12. Kannangara. C.G., S.P. Gough. B. Hansen, J.N. RASMUSSEN \& D.J. SIMPSON: A homogenizer with replaceable razor blades for bulk isolation of active barley plastids. Carlsberg Res. Commun. 42, 431440 (1977)

13. Machold, O.. D.J.Simpson \& B.L. MølleR:Chlorophyll proteins of thylakoids from wild type and mutants of barley (Hordeum vulgare L.). Carlsberg Res. Commun. 44, 235-254 (1979)

14. Majerus, P.W., A.W. Alberts \& P.R. Vagelos: Acyl carrier protein from Eshcerichia coli. Methods Enzymol. XIV, 43-50 (1969)

15. Matsumura, S. \& P.K. StumpF: Fat metabolism in higher plants XXXV. Partial primary structure of spinach acyl carrier protein. Arch. Biochem. Biophys. 125, 932-941 (1968)

16. Matsumura, S., D.N. Brindley \& K. Bloch: Acyl carrier protein from Mycobacterium phlei. Biochem. Biophys. Res. Commun. 38, 369-377 (1970)

17. MCCarthy, A.D., AitKen, A. \& D.G. Hardie: The multifunctional polypeptide chain of rabbit mammary fatty acid synthetase contains a domain homologous with the acyl carrier protein of Escherichia coli. Eur. J. Biochem. 136, 501-508 (1983)

18. MCCarTHY, A.D. \& D. G. Hardie: Fatty acid synthase -an example of protein evolution by gene fusion. TIBS 9, $60-63$ (1984)

19. McKeon, T.A. \& P.K. Stumpf: Purification and characterization of the stearoyl-acyl carrier protein desaturase and the acyl-acyl carrier protein thioesterase from maturing seeds of safflower. J. Biol. Chem. 257, 12141-12147 (1982)

20. OHLROGGE, J.B.. D.N. Kuhn\& P.K. StumpF: Subcellular localization of acyl carrier protein in leaf protoplasts of Spinacia oleracea. Proc. Natl. Acad. Sci. USA 76, 1194-1198 (1979)

21. Rottem, S., O.M. Pered \& S. Razin: Acyl carrier protein in Mycoplasmaa. J. Bacteriol. 113, 586591 (1973)

22. Shimakata, T. \& P.K. Stumpf: Isolation and 
function of spinach leaf $\beta$-ketoacyl(acyl carrier protein) synthases. Proc. Natl. Acad Sci. USA 79, 5808-5812 (1982)

23. Shimakata. T. \& P.K. Stumpf: Fatty acid synthetase of Spinacia oleracea leaves. Plant Physiol. 69, 1257-1262 (1982)

24. Shimakata. T. \& P.K. StumpF: The prokaryotic nature of the fatty acid synthetase of developing Carthamus tinctorius L (Safflower) seeds. Arch. Biochem. Biophys. 217, 144-154 (1982)

25. Simoni, R.D.. R.S. CRIDdLe \& P.K. StUmPF: Fat metabolism in higher plants XXXI. Purification and properties of plant and bacterial acyl carrier proteins. J. Biol. Chem. 242, 573-581 (1967)

26. STUMPF, P.K.: Biosynthesis of saturated and unsaturated fatty acids. In: The Biochemistry of Plants. A Comprehensive Treatise. P.K. Stumpf \& E.E. Conneds. Academic Press, New York, pp. 177-204 (1980)

27. Svendsen, I.. B. Martin \& I. Jonassen: Characteristics of hiproly barley III. Amino acid sequences of two lysine rich proteins. Carlsberg Res. Commun. 45. 79-85 (1980)
28. Takahashi, Y.. T. Hase, K. Wada \& H. MatsuBURA: The second ferredoxin of spinach leaves. J. Biochem. 90, 1825-1828 (1981).

29. Vanaman. T., S.J. Wakil \& R.L. Hill: The complete amino acid sequence of the acyl carrier protein of Escherichia coli. J. Biol. Chem. 243, 6420-6431 (1968)

30. Weeks, G. \& S.J. WakIL: Studies on the mechanism of fatty acid synthesis. Preparation and general properties of the enoyl acyl carrier protein reductases from E. coli. J. Biol. Chem. 243, 1180 1189 (1968)

31. Woodward, J.R. \& G.B. Fincher: Purification and chemical properties of two 1,$3 ; 1,4-\beta$-glucan endohydrolases from germinating barley. Eur. J. Biochem. 121, 663-669 (1982)

32. WOODWARD, J.R. \& G.B. FinCHER: Amino acid sequence homology in two 1,$3 ; 1,4-\beta$-endohydrolases from germinating barley (Hordeum vulgare). FEBS Letters 138, 198-200 (1982) 